\title{
Central Nervous System Activity Studies of Baptisia tinctoria (L.) R. Vent. Roots
}

\author{
Sujata, Deepak Kumar and Suresh Kumar*
}

\author{
Department of Pharmaceutical Sciences and Drug Research, Punjabi University, Patiala-147 002, \\ Punjab, India \\ *thakur_pu@yahoo.com
}

Keywords: Antianxiety, Anticonvulsant, Antistress, Analgesic, Sedative, Wild Indigo.

\begin{abstract}
The present investigations were undertaken with a view to evaluate Baptisia tinctoria roots (Wild Indigo; family - Fabaceae) systematically for neuropharmacological activities. The methanol extract (ME) of plant was prepared by extracting properly identified plant in a Soxhlet apparatus with methanol, after defatting with $n$-hexane. Acute toxicity studies revealed that ME is safe for acute administration. Preliminary phytochemical screening of ME showed presence of alkaloids, steroids, flavonoids, triterpenoids, coumarins and tannins as major classes of phytoconstituents. The ethyl acetate fraction (EAF) was prepared by fractionating crude ME using standardized procedure, which showed presence of flavonoids, alkaloids and triterpenoids. ME $(400 \mathrm{mg} / \mathrm{kg})$ and EAF $(106 \mathrm{mg} / \mathrm{kg})$ produced significant antistress activity in similar manner as exhibited by the sbtandard drug. The ME and EAF exhibited mild antianxiety activity, and were found to be devoid of anticonvulsant, sedative and analgesic activities.
\end{abstract}

\section{Introduction}

Common neurological disorders include depression, anxiety, schizophrenia, seizures and stress, which lead to social isolation and poor quality of life [1]. More than 650 million people suffer from these mental disorders. Around 6-7\% of India's population suffers from a mental disorder either due to stress, depression, anxiety or any other cause [2]. Psychotherapeutics are noneffective in majority of patients with mental health problem but therapeutics having plants and plant products showed potent effect against those mental health problems [3]. The regular use of synthetic drugs causes various unwanted side effects such as damage of cognitive functioning, addiction, physical dependence and tolerance [4]. Due to these adverse effects of synthetic drugs, herbal remedies are preferred now days. India has one of the richest plant based medical tradition in the world. Today, the herbal products demonstrate safety in contrast to the synthetics that are contemplated as unsafe for humans and environment [5]. Traditional systems rely heavily on herbal material compared to modern system of medicine. Despite having long tradition of use in treatment of mental disorders, most of plants have not been validated scientifically [1]. Baptisia tinctoria (L.) $\mathrm{R}$. Vent is one of such plants.

B. tinctoria (Wild Indigo; family - Fabaceae) have been traditionally used in the treatment of neurological disorders in homoeopathic system of medicine, in inability to think, mental confusion, melancholia with stupor and threatened miscarriage from mental depression [6-10]. B. tinctoria has been reported to contain various classes of chemical constituents such as alkaloids, phenols, flavonoids, coumarins and triterpenes. The plant has been reported to exhibit immunomodulatory activity [11]. Despite a long tradition of use, this traditionally used and medicinally promising plant has not been properly investigated for validation of its traditional claims especially in the treatment of CNS diseases. Therefore, it was envisaged to undertake detailed neuropharmacological activity studies on $B$. tinctoria to validate traditional claims of the plant. 


\section{Materials and Methods}

\section{Plant Material}

Baptisia tinctoria roots were procured from a commercial source (Himalaya Herbs Store, Saharanpur, India) in September, 2015. The identity of plant was confirmed by Dr. Avneet Pal Singh, Assistant Professor, Department of Botany, Punjabi University, Patiala, India (Reference No. SPL-105/Bot, dated 12-10-2015).

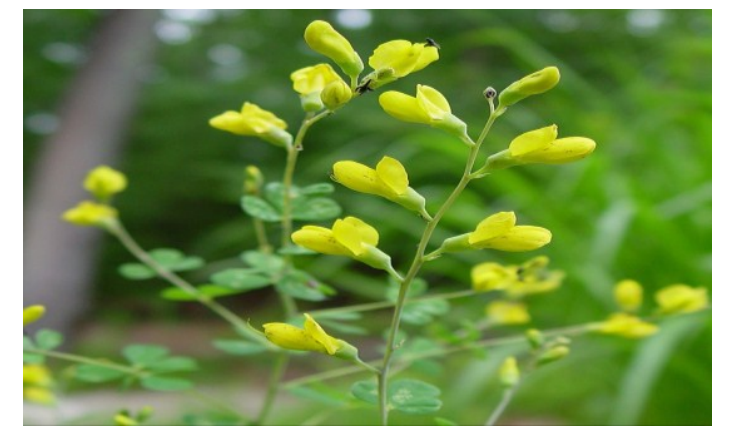

(A)

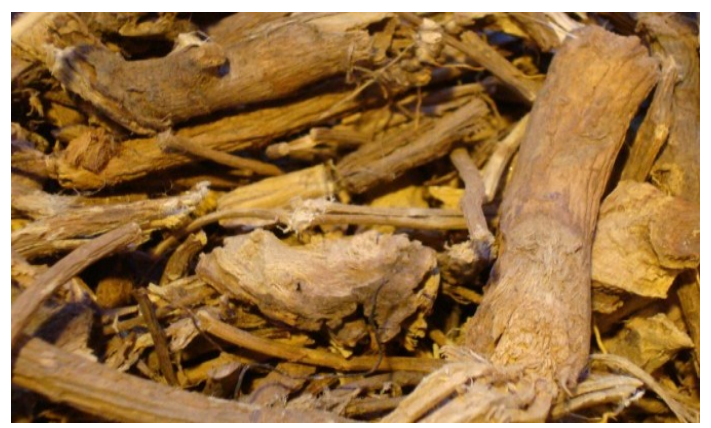

(B)

Figure 1. Baptisia tinctoria (A) aerial parts; (B) roots

\section{Chemicals, Solvents and Reagents}

Methanol, $n$-hexane and ethyl acetate (E Merck, Delhi, India), of LR grade, were used for the preparation of various crude extracts and fractions of $B$. tinctoria roots. The various chemicals and reagents of S.D. Fine Chemicals, Mumbai, India were used in preliminary phytochemical screening.

\section{Animals}

Laca mice (either sex; 20-25 g body weight) purchased from the Central Research Institute, Kasauli, India, were kept in Central Animal House, Punjabi University, Patiala and fed with laboratory pellet diet and water ad libitum. The approval was taken from Institutional Animal Ethics Committee of Punjabi University, Patiala prior to carry out studies on mice (107/99/CPCSEA/201630, dated 27/05/2016). Six animals were used in each group for all sets of experiments.

\section{Preparation of Extracts and Fractions}

Dried and coarsely powdered $B$. tinctoria roots $(0.5 \mathrm{~kg})$ were successively extracted in a Soxhlet apparatus using solvents $(2 \mathrm{~L}$ each) in increasing order of polarity viz., $n$-hexane and methanol. The methanol extract $(10 \mathrm{~g})$ of plant material was suspended uniformly in water, and partitioned successively with ethyl acetate as per standard procedure [1]. The various extract / fractions were concentrated by recovering solvent under reduced pressure in a rotary vacuum evaporator to get $n$-hexane extract (HE), methanol extract (ME), ethyl acetate fraction (EAF) and remaining methanol extract (RME). The percentage yield (\% w/w) of ME and EAF was recorded in relation with plant and ME respectively. Various extracts / fractions were also screened for presence of different classes of phytoconstituents [12].

\section{Acute Toxicity Studies}

The guidelines-423 of Organization for Economic Cooperation and Development (OECD) was followed for acute oral toxicity study of $\mathrm{ME}$ of $B$. tinctoria roots at a single dose of $2000 \mathrm{mg} / \mathrm{kg}$, p.o. [1].

\section{Vehicle and Standard Drugs}

Distilled water + Tween $80(2 \%)$ was used as vehicle. The doses of test substances were prepared in vehicle. Diazepam (Jackson Laboratories Pvt. Ltd., Amritsar, Punjab, India; $1 \mathrm{mg} / \mathrm{kg}$, i.p.), diazepam (2 mg/kg, i.p.), diazepam (1 mg/kg, i.p.), phenytoin (Abbott Healthcare Pvt. Ltd., Mumbai, India; $20 \mathrm{mg} / \mathrm{kg}$, i.p.) and pentazocine (Ind-Swift Limited, Nalagarh, Solan, Himachal 
Pradesh, India; $10 \mathrm{mg} / \mathrm{kg}$, i.p.), were used as standard antistress, antianxiety, sedative, anticonvulsant and anlgesic drugs respectively. Thiopentone sodium (40 mg/kg, i.p.), standard sedative drug was administered to mice of all groups in thiopentone sodium- induced sleep assay to induce sleep. The sedative activity of thiopentone sodium (Neon Laboratories Limited, Mumbai, India; $40 \mathrm{mg} / \mathrm{kg}$, i.p. $)$ was further potentiated by another standard drug, diazepam $(1 \mathrm{mg} / \mathrm{kg}$, i.p).

\section{Experimental Design}

A total of five experimental protocols were designed to study different neuropharmacological activities of $B$. tinctoria roots. In each experimental protocol, five groups were made as described follow:

Group I - Control group received vehicle; Group II - Standard group received respective standard drug; Groups III and IV - Test groups received different doses of ME (200 or $400 \mathrm{mg} / \mathrm{kg}$, p.o.) and Groups V - Test group received single dose of EAF (106 mg/kg, p.o.) respectively.

\section{Neuropharmacological Activities}

The well-established experimental models, i.e., cold swin test, elevated plus maze model, thiopentone sodium-induced sleeping assay, maximal electroshock test and tail immersion test for assessment of antistress, antianxiety, sedative, anticonvulsant and analgesic activities respectively $[1,13]$.

\section{Statistical Analyses}

The results have been expressed as mean \pm standard deviation (S.D.). The test drugs were compared with standard drug and control by one-way analysis of variance (ANOVA) followed by Student-Newman-Keul's test [14].

\section{Results}

\section{Phytochemical Screening and Acute Toxicity Studies}

The percentage yield (w/w) of ME of $B$. tinctoria roots was found to be $16.98 \% \mathrm{w} / \mathrm{w}$. The ME was further fractionated with ethyl acetate. Yield of EAF was found to be $26.58 \% \mathrm{w} / \mathrm{w}$ in relation to the ME. The HE, ME, EAF and RME of B. tinctoria roots were screened for different classes of phytoconstituents using specific standard reagents. Phytochemical screening showed presence of fixed oils in HE; proteins, carbohydrates, alkaloids, flavonoids, steroids, triterpenoids, tannins and coumarins in ME; alkaloids, flavonoids, steroids, triterpenoids, tannins and coumarins in EAF and proteins, carbohydrates in RME. Preliminary phytochemical screening showed the presence of only fixed oils in $\mathrm{HE}$ of $B$. tinctoria roots. HE was not subjected to acute toxicity studies as it was used only for defatting of plant material. No mortality and lethality was observed in mice treated with $2 \mathrm{~g} / \mathrm{kg}$ dose of the ME of $B$. tinctoria roots. CNS studies of ME of B. tinctoria roots were performed at 200 and $400 \mathrm{mg} / \mathrm{kg}$, i.e., $1 / 10^{\text {th }}$ and $1 / 5^{\text {th }}$ dose employed in acute toxicity studies.

\section{Antistress Activity}

The ME and EAF of B. tinctoria roots were evaluated for antistress activity in mice using cold swim test. The ME $(400 \mathrm{mg} / \mathrm{kg})$ and EAF $(106 \mathrm{mg} / \mathrm{kg})$ significantly reduced duration of immobility in mice with respect to control and statistically equivalent to the standard drug (Table 1).

\section{Antianxiety Activity}

The ME and EAF of $B$. tinctoria roots were screened for antianxiety activity in mice using EPM model. The ME (200 or $400 \mathrm{mg} / \mathrm{kg})$ and EAF $(106 \mathrm{mg} / \mathrm{kg})$ significantly increased number of entries and average time spent by mice in open arms of EPM with respect to control, but therapeutic level equivalent to the standard drug was not achieved at all tested doses (Table 1). The results suggest that ME and EAF of $B$. tinctoria roots exhibit mild antianxiety activity. 


\section{Sedative Activity}

Potentiation of thiopentone sodium induced-sleeping time assay was employed to assess sedative activity of the ME and EAF of $B$. tinctoria roots. The mean latency time and duration of sleep after acute oral administration of methanol extract $(200$ or $400 \mathrm{mg} / \mathrm{kg}$, p.o.), EAF (106 mg/kg, p.o.), diazepam (1 mg/kg, i.p.) and the control (vehicle) have been shown in table 1. In this assay, thiopentone sodium $(40 \mathrm{mg} / \mathrm{kg}$, i.p. $)$ was administered to all groups of mice to induce sleep. The standard drug, diazepam at the dose of $1 \mathrm{mg} / \mathrm{kg}$ significantly potentiated thiopentone sodiuminduced sleep in mice with respect to the control. It is clearly evident form the table 1 that mean duration of sleep observed in mice treated with vehicle was $49.66 \mathrm{~min}$, whereas standard drug potentiated sleep in mice to $86.33 \mathrm{~min}$. The mean duration of sleep observed in groups of mice treated with $\mathrm{ME}$ and EAF was statistically equivalent to the vehicle treated group. These observations infer that ME and EAF were devoid of sedative activity.

\section{Anticonvulsant Activity}

All extracts of $B$. tinctoria roots were subjected to anticonvulsant activity in mice using maximal electro-shock test. It is clearly evident from table 1 that ME and EAF were devoid of anticonvulsant activity as mean duration of extensor phase in mice treated with ME and EAF were found to be statistically equivalent to control group of mice treated with vehicle. On the other hand, phenytoin (a standard anticonvulsant drug) significantly reduced duration of extensor phase in mice and protected all the mice from mortality due to MES- induced convulsions.

Table 1. Antistress, Antianxiety, Sedative and Anticonvulsant Activities of ME and EAF of B. tinctoria Roots

\begin{tabular}{|c|c|c|c|c|c|c|c|c|}
\hline \multirow{2}{*}{$\begin{array}{c}\text { Treat- } \\
\text { ment }\end{array}$} & \multirow{2}{*}{$\begin{array}{c}\text { Dose } \\
(\mathrm{mg} / \mathrm{kg})\end{array}$} & \multirow{2}{*}{$\begin{array}{c}\text { Antistress } \\
\text { activity }^{-} \\
\text {Mean }^{n} \\
\text { immobility } \\
\text { time (sec) }\end{array}$} & \multicolumn{2}{|c|}{ Antianxiety activity } & \multicolumn{2}{|c|}{ Sedative activity } & \multicolumn{2}{|c|}{ Anticonvulsant activity } \\
\hline & & & $\begin{array}{c}\text { Mean }^{n} \\
\text { number } \\
\text { of entries } \\
\text { in open } \\
\text { arms }\end{array}$ & $\begin{array}{l}\text { Mean }^{n} \text { time } \\
\text { spent in } \\
\text { open arms } \\
\text { (sec) }\end{array}$ & $\begin{array}{c}\text { Mean }^{n} \\
\text { latency } \\
\text { time (min) }\end{array}$ & $\begin{array}{c}\text { Mean }^{n} \\
\text { duration of } \\
\text { sleep (min) }\end{array}$ & $\begin{array}{c}\text { Mean }^{n} \\
\text { duration of } \\
\text { extensor } \\
\text { phase (sec) }\end{array}$ & $\begin{array}{l}\text { Percentage } \\
\text { protection }\end{array}$ \\
\hline Control & $\begin{array}{l}\text { Vehic- } \\
\text { le }\end{array}$ & $\begin{array}{c}141.16 \pm \\
8.01^{\mathrm{a}}\end{array}$ & $\begin{array}{c}2.50 \pm \\
0.54^{\mathrm{a}}\end{array}$ & $\begin{array}{c}4.33 \pm \\
0.51^{\mathrm{a}}\end{array}$ & $\begin{array}{c}16.88 \pm \\
0.34\end{array}$ & $\begin{array}{c}49.66 \pm \\
4.08^{\mathrm{a}}\end{array}$ & $\begin{array}{c}29.02 \pm \\
1.20^{\mathrm{a}}\end{array}$ & 50 \\
\hline Diazepam & 1 & $\begin{array}{c}37.83 \pm \\
5.07^{*}\end{array}$ & 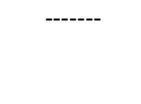 & 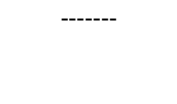 & --- & --- & ----- & --- \\
\hline Diazepam & 2 & 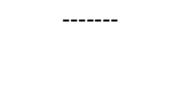 & $\begin{array}{c}9.83 \pm \\
1.47^{*}\end{array}$ & $\begin{array}{c}13.00 \pm \\
1.67^{*}\end{array}$ & 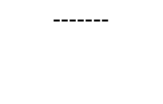 & --- & 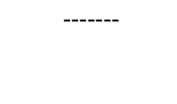 & ---- \\
\hline Diazepam & 1 & 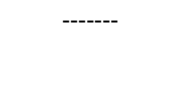 & 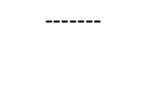 & 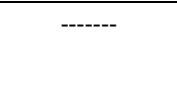 & $\begin{array}{c}17.20 \pm \\
0.81\end{array}$ & $\begin{array}{c}86.33 \pm \\
3.83^{*}\end{array}$ & ---- & 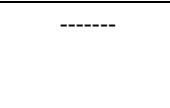 \\
\hline Phenytoin & 20 & ---- & --- & ---- & --- & - & $\begin{array}{l}1.08 \pm \\
0.09^{*}\end{array}$ & 100 \\
\hline \multirow[t]{2}{*}{$M E$} & 200 & $\begin{array}{c}52.50 \pm \\
5.24^{* \mathrm{a}_{\mathrm{a}}}\end{array}$ & $\begin{array}{l}4.50 \pm \\
0.54^{* a}\end{array}$ & $\begin{array}{l}7.33 \pm \\
1.21^{* a}\end{array}$ & $\begin{array}{c}16.47 \pm \\
0.65\end{array}$ & $\begin{array}{c}53.83 \pm \\
3.48^{\mathrm{a}}\end{array}$ & $\begin{array}{c}27.72 \pm \\
2.01^{\mathrm{a}}\end{array}$ & $\begin{array}{c}50 \\
66.66\end{array}$ \\
\hline & 400 & $\begin{array}{c}38.50 \pm \\
3.67^{*}\end{array}$ & $\begin{array}{l}5.66 \pm \\
1.03^{* a}\end{array}$ & $\begin{array}{l}8.33 \pm \\
1.36^{* a}\end{array}$ & $\begin{array}{c}17.99 \pm \\
0.45\end{array}$ & $\begin{array}{c}54.66 \pm \\
3.55^{\mathrm{a}}\end{array}$ & $\begin{array}{c}28.41 \pm \\
3.14^{\mathrm{a}}\end{array}$ & \\
\hline$E A F$ & 106 & $\begin{array}{c}36.50 \pm \\
3.98^{*}\end{array}$ & $\begin{array}{l}6.80 \pm \\
0.75^{* a}\end{array}$ & $\begin{array}{l}8.50 \pm \\
1.04^{* a}\end{array}$ & $\begin{array}{c}17.98 \pm \\
0.12\end{array}$ & $\begin{array}{c}55.16 \pm \\
6.33^{\mathrm{a}}\end{array}$ & $\begin{array}{c}28.76 \pm \\
2.58^{\mathrm{a}}\end{array}$ & 66.66 \\
\hline
\end{tabular}

$\mathrm{n}=6$; The data is expressed as Mean \pm S.D.; ${ }^{*} P<0.05$ vs. Control; ${ }^{\mathrm{a}} P<0.05$ vs. Standard; one-way ANOVA followed by Student-Newman-Keul's test.

\# Thiopentone sodium $(80 \mathrm{mg} / \mathrm{kg}$, i.p. $)$ was administered to all mice treated with control, diazepam, ME and EAF. 


\section{Analgesic Activity}

In tail immersion test, time taken by the mice to with draw its tail from the heat (flicking response) is recorded. This flicking response is taken as a parameter to assess analgesic activity of test substances. After acute treatment with ME (200 or $400 \mathrm{mg} / \mathrm{kg}$, p.o. $)$, EAF (106 mg/kg, p.o.), pentazocine $(10 \mathrm{mg} / \mathrm{kg}, i . p$.) and vehicle, p.o., the time taken by mice to with draw their tail from hot water was recorded. The results of the study have been presented in table 2 . The standard drug, pentazocine, exhibited analgesic activity for whole period of study with respect to control. The maximum percent MPE (67.84\%) was observed in mice after $30 \mathrm{~min}$ of treatment of pentazocine, while after $3 \mathrm{~h}$ of treatment \% MPE was $30.11 \%$. These observations suggest that the analgesic activity of standard drug was decreased with the passage of time due to metabolism of drug. None of the test doses of ME and EAF showed analgesic activity in mice. Similar flicking response was observed in mice treated with ME and EAF as shown by mice of control group.

Table 2. Analgesic Activity of ME and EAF of B. tinctoria Roots

\begin{tabular}{|c|c|c|c|c|c|c|c|c|c|c|}
\hline \multirow{2}{*}{$\begin{array}{l}\text { Treatment } \\
\text { group }\end{array}$} & \multirow{2}{*}{$\begin{array}{c}\text { Dose } \\
(\mathrm{mg} / \mathrm{kg})\end{array}$} & \multirow{2}{*}{$\begin{array}{c}\text { Mean }^{n} \\
\text { basal }^{2} \\
\text { reading } \\
(\mathrm{sec})\end{array}$} & \multicolumn{4}{|c|}{ Mean $^{n}$ reaction time (sec) } & \multicolumn{4}{|c|}{$\%$ Maximal possible effect } \\
\hline & & & $30 \mathrm{~min}$ & $1 \mathrm{~h}$ & $2 h$ & $3 h$ & $30 \mathrm{~min}$ & $1 \mathrm{~h}$ & $2 h$ & $3 h$ \\
\hline Control & Vehicle & $\begin{array}{c}2.20 \pm \\
0.11\end{array}$ & $\begin{array}{c}3.48 \pm \\
0.02^{\mathrm{a}}\end{array}$ & $\begin{array}{l}3.00 \pm \\
0.01^{\mathrm{a}}\end{array}$ & $\begin{array}{c}2.50 \pm \\
0.32^{\mathrm{a}}\end{array}$ & $\begin{array}{c}2.30 \pm \\
0.11^{\mathrm{a}}\end{array}$ & 10 & 6.25 & 2.34 & 0.78 \\
\hline Pentazocine & 10 & $\begin{array}{c}2.25 \pm \\
0.13\end{array}$ & $\begin{array}{c}10.90 \\
\pm 0.13^{*}\end{array}$ & $\begin{array}{l}9.40 \pm \\
0.12^{*}\end{array}$ & $\begin{array}{l}7.00 \pm \\
0.22^{*}\end{array}$ & $\begin{array}{c}6.09 \pm \\
0.12^{*}\end{array}$ & 67.84 & 56.07 & 37.25 & 30.11 \\
\hline \multirow[t]{2}{*}{$M E$} & 200 & $\begin{array}{c}2.22 \pm \\
0.01\end{array}$ & $\begin{array}{c}3.50 \pm \\
0.12^{\mathrm{a}}\end{array}$ & $\begin{array}{c}3.12 \pm \\
0.04^{\mathrm{a}}\end{array}$ & $\begin{array}{c}2.60 \pm \\
0.11^{\mathrm{a}}\end{array}$ & $\begin{array}{c}2.35 \pm \\
0.21^{\mathrm{a}}\end{array}$ & 10.01 & 7.04 & 2.97 & 1.02 \\
\hline & 400 & $\begin{array}{c}2.25 \pm \\
0.07\end{array}$ & $\begin{array}{c}3.79 \pm \\
0.11^{\mathrm{a}}\end{array}$ & $\begin{array}{c}3.16 \pm \\
0.01^{\mathrm{a}}\end{array}$ & $\begin{array}{c}2.50 \pm \\
0.02^{\mathrm{a}}\end{array}$ & $\begin{array}{c}2.30 \pm \\
0.31^{\mathrm{a}}\end{array}$ & 12.07 & 7.14 & 1.96 & 0.39 \\
\hline$E A F$ & 106 & $\begin{array}{c}2.30 \pm \\
0.04\end{array}$ & $\begin{array}{c}3.88 \pm \\
0.04^{\mathrm{a}}\end{array}$ & $\begin{array}{c}3.08 \pm \\
0.01^{\mathrm{a}} \\
\end{array}$ & $\begin{array}{c}2.70 \pm \\
0.04^{\mathrm{a}}\end{array}$ & $\begin{array}{c}2.50 \pm \\
0.21^{\mathrm{a}}\end{array}$ & 12.44 & 6.11 & 3.14 & 1.57 \\
\hline
\end{tabular}

$\mathrm{n}=6$; The data is expressed as Mean \pm S.D.; $* P<0.05$ vs. Control; ${ }^{\text {a }} P<0.05$ vs. Standard drug; one-way ANOVA followed by Student-Newman-Keul's test.

\section{Discussion}

Phytochemical screening showed presence of fixed oils in HE, whereas proteins, carbohydrates, alkaloids, flavonoids, steroids, triterpenoids, tannins and coumarins in ME. The purpose of extracting plant material with $n$-hexane was to remove lipids from the plant. Thus, HE was not used for screening neuropharmacological activities. Acute toxicity studies were carried out on ME. No mortality and lethality was observed in mice treated with ME $(2 \mathrm{~g} / \mathrm{kg})$. Therefore, toxicity was not performed on lower doses of extract. The ME was further fractionated using ethyl acetate. The ME and EAF of $B$. tinctoria roots were screened for neuropharmacological activities such as antistress, antianxiety, sedative, anticonvulsant and analgesic activities. RME was not tested for activities because it did not show presence of any major class of phytoconstituents.

Increased levels of adrenocorticoids induces stress in animals [15]. Cold swim test was employed to assess antistress activity of test substances because a sharp increase in level of adrenocorticoids has been recorded when animals are individually allowed to swim in a cold environment. A significant reduction of mean time spent in cold environment by mice treated with $\mathrm{ME}$ and EAF with respect to control inferred their antistress potential. EPM model was employed to assess antianxiety activity of ME and EAF of $B$. tinctoria roots. ME and EAF decreased acrophobia induced motor activity in mice significantly with respect to control but not equivalent to standard drug inferring their mild antianxiety activity [16]. To assess sedative activity, latency time and duration of sleep were recorded in mice after administration of test drugs using potentiation of 
thiopentone sodium-induced sleeping time assay. Diazepam was used as standard drug because it potentiates GABA mediated postsynaptic inhibition through allosteric modification of $\mathrm{GABA}_{\mathrm{A}}$ receptors and increase the duration of sleep [17]. The test drugs were found to be devoid of sedative activity as these failed to increase duration of sleep in mice. MES-induced convulsions assay was employed in present study for the assessment of anticonvulsant potential of test drugs. Inhibition of tonic extension in mice using MES test suggest anticonvulsant activity against generalized tonicclonic and cortical focal seizures as shown by the standrad drug, phenytoin [18]. But the test substances were devoid of anticonvulsant activity as these drugs could not decrease duration of extensor phase in mice with respect to control. The analgesic activity of the standard and test drugs was assessed in tail immersion test. In this test, tail of animal is placed in hot water results in flicking response (withdrawal of tail from hot water) due to pain. Analgesic drugs significantly increase pain threshold in animals by the involvement of a higher centre [19]. The standard drug showed significant analgesic activity with respect to control during $3 \mathrm{~h}$ of study, whereas test drugs (ME and EAF) did not show analgesic activity at any tested dose.

Preliminary phytochemical studies showed presence of flavonoids, alkaloids and triterpenoids in bioactive EAF of B. tinctoria roots. Flavonoids - chrysin [20], apigenin [21], naringenin [22]; Alkaloids - berberine [23], pleiocarpine, kopsinine [24]; Triterpenoids - maslinic acid [25], oleanolic acid [26], isolated from plant drugs, have shown significant neuropharmacological activities. The results of present investigations are in agreement to above reports. The antistress activity of $B$. tinctoria roots is attributed to these bioactive groups of phytoconstituents.

\section{Conclusion}

Finally, it can be concluded that methanol extract, containing bioactive classes of phytoconstituents such as flavonoids, alkaloids and triterpenoids, exhibits significant antistress activity. Ethyl acetate fraction takes up most bioactive constituents of methanol extract. Ethyl acetate fraction exhibits strong antistress and mild antianxiety, and is devoid of anticonvulsant, sedative and analgesic activities.

\section{Acknowledgements}

Authors duly acknowledge Prof R.C. Gupta, Co-ordinator of DBT-IPLS project for providing access to instrumentation facilities at Punjabi University, Patiala.

\section{References}

[1] O. Prakash, D. Kumar, S. Kumar, Screening of methanol extract and ethyl acetate fraction of Abies webbiana Lindl. for neuropharmacological activities, Indian J. Pharm. Sci. 77 (2015) 536-541.

[2] B. Ghanashyam, S. Nagarathinam, India is failing the mentally ill as abuses continuing, Lancet. 376 (2010) 1633-1634.

[3] S. Sandhya, K.R. Vinod, S. Kumar, Herbs used for brain disorders, Hygeia J. Drugs Med. 2 (2010) 38-45.

[4] R.J. Baldessarini, Drugs and the treatment of psychiatric disorders, in: J.G. Hardman, L.E. Limbird (Eds.), Goodman and Gilman's The Pharmacological Basis of Therapeutics, New York, McGraw- Hill, 2001, p 987.

[5] S. Noor et al., Evaluation of anti-inflammatory and antidiabetic activity of ethanolic extract of Desmodium pulchellum Benth (Fabaceae) barks on albino wistar rats, Journal of Applied Pharmaceutical Science. 3(7) (2013) 48-51.

[6] P. Bergner, Nervous depression and homeopathic indications of herbs, Med. Herb. 9 (1995) 12. 
[7] W. Boericke, Homeopathic materia medica, Presented by Medi T, 1999, Information on: http://www.homeoint.org/books/boericmm/b/bapt.html.

[8] J.W. Fyfe, The Essentials of modern materia medica and therapeutics, Eclectic Manual No. 6, Cincinnati, The Scudder Brothers Company, 1903, p. 15.

[9] F.J. Petersen, Materia medica and clinical therapeutics, Published by F.J. California, Petersen Los Olivos, 1905, p. 51.

[10] S. Tilgner, Wild Indigo: Baptisia tinctoria, Presented by Materia Medica, 1999, Information on: http:/www.herbaltransitions.com/materiamedica/Baptisia.html.

[11] A. Pengelly, K. Bennett, Appalachian plant monographs: Baptisia tinctoria (L.) R.Vent., Wild Indigo, Maryland, Tai Sophia Institute, 2011, pp 1-15. Retrieved from http://www.frostburg.edu/aces/appalachian-plants/

[12] N.R. Farnsworth, Biological and phytochemical screening of plants, J. Pharm. Sci. 55 (1966) 225-276.

[13] F. Sharmen et al., Investigation of in vivo neuropharmacological effects of Alpinia nigra leaf extract, Asian Pac. J. Trop. Biomed. 4 (2014) 137-142.

[14] W.C. Scheffer, Statistics for the Biological Sciences, Philippines, Addison-Wesley Publishing Company, 1980, pp. 121-141.

[15] M. Komiya, T. Takeuchi, E. Harada, Lemon oil vapour causes an anti-stress effect via modulating the 5-HT and DA activities in mice, Behav. Brain Res. 172 (2006) 240-249.

[16] C. Belzung, G. Griebel, Measuring normal and pathological anxiety like behaviour in mice: A review, Behav. Brain Res. 152 (2001) 141-149.

[17] M.O. Raihan et al., Sedative and anxiolytic effects of the methanolic extract of Leea indica (Burm. f.) Merr. Leaf, Drug Discov. Ther. 5 (2011) 185-189.

[18] E.A. Swinyard, W.C. Brown, L.S. Goodman, Comparative assays of antiepileptic drugs in mice and rats, J. Pharmacol. Exp. Ther. 3 (1952) 319-330.

[19] R. Madaan, S. Kumar, Screening of alkaloidal fraction of Conium maculatum Linn. aerial parts for analgesic and anti-inflammatory activity, Indian J. Pharm. Sci. 74 (2012) 457-460.

[20] C. Wolfman et al., Possible anxiolytic effects of chrysin, a central benzodiazepine receptor ligand isolated from Passiflora Coerulea, Pharmacol. Biochem. Behav. 47 (1994) 1-4.

[21] S. Kumar, A. Sharma, Apigenin: The anxiolytic constituent of Turnera aphrodisiaca, Pharm. Biol. 44 (2006) 84-90.

[22] L.T. Yi et al., Involvement of monoaminergic system in the antidepressant-like effect of the flavonoid naringenin in mice, Prog. Neuropsychopharmacol. Biol. Psychiatry. 34 (2010) $1223-1228$

[23] S.K. Kulkarni, A. Dhir, Berberine: A plant alkaloid with therapeutic potential for central nervous system disorders, Phytother. Res. 24 (2010) 317-324.

[24] H. Naaz et al., Anti-cholinergic alkaloids as potential therapeutic agents for Alzheimer's disease: An in silico approach, Indian J. Biochem. Biophys. 50 (2013) 120-125.

[25] Y. Qian et al., Maslinic acid, a natural triterpenoid compound from Olea europaea, protects cortical neurons against oxygen-glucose deprivation-induced injury, Eur. J. Pharmacol. 670 (2011) 148-153.

[26] R. Martin et al., Beneficial actions of oleanolic acid in an experimental model of multiple sclerosis: A potential therapeutic role, Biochem. Pharmacol. 79 (2010) 198-208. 